

RAST MUSICOLOGY JOURNAL

RAST

International Musicology Journal

www.rastmd.com

\title{
THE INFLUENCES AND CHANGES OF THE CRIMEAN TATARS MUSIC IN THE PROCESS
}

\author{
Asst. Prof. Dr. Abdullah AKAT ${ }^{1}$ \\ Karadeniz Techical University State Conservatory \\ Turkiye \\ a.akat@hotmail.com
}

\section{ABSTRACT}

Crimea is now an autonomous parliamentary republic which is governed by the Constitution of Crimea in accordance with the laws of Ukraine. But, Crimea has been home to different nations during the history, as a result of the cultural wealth and this factor has been moved to today patterns. Crimean Tatars is one of the important parts of this wealth. The Crimean Tatars were forcibly expelled to Central Asia by Joseph Stalin's government after II. World War. After the fall of the Soviet Union, some Crimean Tatars began to return to the region. Now, Crimean Tatars, an ethnic minority in Crimea and make up about $13 \%$ of the population. So, Crimean Tatars' music must be evaluated in two periods. Before exile and after exile. There are many networks in the music of the Crimea, and these networks can continue their existence even in small villages. On the other hand, the effects of popular culture increasing on Crimean Tatars music. The aim of this paper is to explain the musical differences in the process of change in music of the Crimean Tatars from generation to generation; define the effects of the people, places and mass media that cause them, observe them in daily practice and analyze these type of issues.

\footnotetext{
${ }^{1}$ Third Symposium of The ICTM Study Group for Music of The Turkic Speaking World, 1-2 Dec, 2012, Cambridge, UK.
} 
Key Words: Crimea, Crimean Tatars, Music, Exile, Change, Popular Culture.

\section{ÖZET}

Tarih boyunca farklı milletlere ev sahipliği yapmış olan Kırım coğrafyası bunun sonucunda çeşitli kültürel zenginlikleri içermektedir. Kırım Tatarları da bu zenginliğin önemli parçalarından biridir. II. Dünya Savaşı’ndan sonra Joseph Stalin yönetimi tarafından Orta Asya'ya zor kullanılarak sürgün edilen Kırım Tatarları, ancak Sovyetler Birliği'nin dağılmasından sonra Kırım'a geri dönebilmişlerdir. Günümüzde Kırım Tatarları, Kırım Özerk Cumhuriyeti içinde \%13'lük bir nüfus oluşturan etnik bir azınlık durumundadır ve Ukrayna yasalarına bağlı olarak yönetilmektedir. Dolayısıyla, Kırım Tatarlarının müziği sürgün öncesi ve sürgün sonrası olmak üzere iki dönem içinde değerlendirilebilir. Kırım müziklerinin içinde sayısız ağlar bulunmaktadır ve oldukça büyük bir alana yayılmıştır. Bu ağlar varlıklarını yalnızca Kırım'da değil, Anadolu'da, Balkanlarda ve göç yolları üzerindeki birçok küçük yerleşimlerde dahi devam ettirebilmektedir. Diğer taraftan, Kırım Tatar müzikleri üzerinde popüler kültürün etkileri de giderek artmaktadir.

$\mathrm{Bu}$ makalenin amacı, Kırım Tatarlarının kuşaktan kuşağa taşıdığı müziklerinin zaman içerisindeki değişimlerini ve müzikal farklılıklarını açıklamak, insan, mekan ve kitle iletişim araçları gibi değişime sebep olan kaynakları gündelik yaşam pratiklerinde gözlemlemek ve etkilerini ortaya koyabilmektir.

Anahtar Kelimeler: Kırım, Kırım Tatarları, Müzik, Sürgün, Değişim, Popüler Kültür

It is very important to answer carefully the questions of how long Tatars have been living in Crimea and in which conditions and political structures they appeared in. Crimea is located at the north of the Black Sea. And as the opening gate to the sea of this region, Crimea is very important socially, culturally, economically and geopolitically. 
Tatars have been living in Crimea since 13th century and they built some powerful states, for instance, Altınorda Empire and Crimean Khanates. But in some parts of the history, Tatars were living under the control of other states such as Ottoman Empire, Tsarist Russia and later Soviet Russia. The Crimean Tatars were forcibly expelled to Siberia and Central Asia, especially Uzbekistan, in one night, by Joseph Stalin's government after II. World War and their return to homeland was banned. After the fall of the Soviet Union, some Crimean Tatars began to return to Crimea, but nothing was like before.

Today, Crimea is an autonomous parliamentary republic which is governed by the Constitution of Crimea in accordance with the laws of Ukraine. The Crimean Tatars, an ethnic minority in Crimea, make up about $12-13 \%$ of the population. On the other hand, Crimea has been home to different nations during the history such as Ukraines, Russians, Armenians, Georgians, Germans and ext. Thus, Crimea has a multi-cultural structure and Tatars form one of the biggest parts of this structure. So, if we look at historical events, we can see that the Crimean Tatars' music is very sophisticated and there are many networks in the music of the Crimea.

In general, Crimean Tatars' music must be evaluated in two periods; before exile and after exile. But, this consideration is not enough by itself. Because the big part of the Tatars population migrated to Caucasians, Balkans and Anatolia after Tatars lost the domination in Crimea in 1783. Thus, Crimean Tatars spread quite a large area: Romania, Bulgaria, Litvania, Polonia, Georgia and Turkiye. In this way, the Crimean Tatars began to have strong cultural interactions in a large geographical area. Until the end of the 19th century, Tatars, who lived in Crimea or outside the Crimea, could only think about existence and fell into a struggle for survival. This period is considered as a period of sleep for Tatars.

After this period, Ismail Gaspirali (1851-1914), who is a great writer and literaturer, started a national awakening with his ideas, especially with the words "the unity in language, thought and action" (Gaspirali, 1911). This awakening gradually turned into a national struggle and thus provided a large unity in Tatars which scattered in the 
Balkans and Anatolia. Today, we can learn many things about Crimean Tatars' culture and music through this awakening and togetherness. After the awakening, Crimean Tatars organized a number of national activities, firstly in Balkans and Romania and then the other countries which Tatars lived in. After that, this organization grew and extended through Crimea. Folk music that reflects a great artistic power, daily working manners, traditions, social relationships within the family, becomes important again and as well as national. Thus, folk or national music becomes one of the most important parts of the spiritual culture of the Crimean Tatar people.

There were a lot of genres in Crimean Tatar folk music and all of them used from Crimea to Balkans and Anatolia in the first quarter of the 20th century. Those genres are yırs, ninnis, child songs, agricultural traditions, Ramadan month traditions, wedding music, çıns/şıns, dances music, especially kaytarmas, and a beyt genre in Nogay Tatars music. Yırs has the oldest written works within these genres. In 1910, "Kırım Türkleri'nin Yırları" was published by A. Olesnitski. In this book, there are more than 60 yurs compiled from villages in Crimea. And also Russian folklorists A. Konçevski, V. Filenenko and S. Efetov, who has researched many sources about Crimean Turks folklore, studied on collections and publications about yırs. Çıns is an important genre, due to its choreography and verbal expression and it is like a mix dance and musical theatre. Hence, çıns and legends described in the çıns have a strong influence on the public.

Crimean Folk Dances were shown on the stage first time by Hayri Emirzade (1893-1959) in Crimea. And Emin Bektöre studied on compilations of folk music and performances of folk dance in Romania after 1929. And a number of musician, dancer, composer, compiler, choreographer, conducter worked for Crimean folk music and dance such as Hüseyin Bakkal, Şehzade Mahmutova, Şevket Mahmutov, Edim Şakirov, İzzet Dobra, Hanife Çolakova, Selime Çelebiova, Rıfat Hasanov, Rüstem Gaziyev and ext.

On the other hand, after Gaspirali's dead, the national struggle was taken over by Numan Çelebi Cihan (1885-1918). Çelebi Cihan and his friends formed a national council in 1917, but it didn't last too long. Çelebi Cihan was killed in 1918. After his dead, 
Müstecip Ülküsal continued the national struggle with various activities. 'The Journal of Emel' published in 1930 and it was aiming to raise awareness of public in every respect and also protect folk/national music and culture. National cadres worked on collecting and publishing Crimean Turks folk music.

Y. Şerfedinov and A. Refatov went on an ethnographic tour starting from Akmescit, through Saravuz, Abzlar, Kerç, Kırk Çolpan, Canköy, Tüp Kenegez, KoleçMeçet, Eski Kırım, Ay-Serez, Kapskor, Üsküt and Karasubazar. They compiled very important datum in 1925. As a result of this tour, A. Refatov collected about 150 ylrs, çıns and musical pieces. Those activities have spread Romania, Bulgaria, Litvania, Polonia, Hungary, Germany and also Turkiye. "Kırım Tatar Yır ve Oyunları" was published by Y. Şerfedinov and "Kırım Yırları" was published by A. Feratov in 1931. And also yır books were published for children in those years.

Folk culture was at its peak between 1937 and 1940. Kurt Seyit Çali was conducting Aluşta Crimean Tatar Dance Group. There were many instrumentalists and vocal performers in Crimea. Violin, Zurna, Santur, Accordion and Dâre were played commonly during this period. After the decision of establishment of Autonomous Republic of Crimea in May 1940, Republican Crimean Tatar Dance Ensemble has occurred through joining of Simferopol and Yalta communities. In addition to this, there were some amateur artistic groups in certain places.

After the exile in 18 May 1944, everything stopped. It was a dark night for Tatars and their return and recover was enormously hard. Until 1956, there was nothing as music groups or alike. The music has solely performed in Romania and Turkiye on some special days and at exhibitions. Emin Bektöre came to Turkiye and settled in Eskişehir, carrying out significant work for Tatars folk culture. During World War II, Bilal Menekay founded the ensemble "Çankaya" while he was a captive in German Mittenwald Working Camp. After the war, he came to Turkey, Istanbul and worked on Tatar folk culture. In 1956, Kaytarma Ensemble was founded in Uzbekistan and until 1985, it was the unique Tatar music ensemble with 40 artists, performing all around the Soviet Union. Between 1960 and 1980, amateur folk dance or music groups could be seen performing in Uzbekistan 
and Tajikistan. Thus, we can observe that Crimean Tatars tried to protect their cultural species and togetherness.

As a result of a long struggle, under the leadership of Mustafa Cemiloğlu, Crimean Tatars began to return to their homeland in 1980's. After returning to the homeland, Crimean Tatars did not have a problem in the area of art and re-established their ensembles. Just like other Tatars, "Kaytarma" ensemble has also come back to Crimea and continued their performances there. Since 1990, a number of ensembles were founded in Crimea by folk artists and intellectuals. Among them are "Kırım", "Uçansuv", "Horan", "Tesselli", "Fidanlar" and ext. After a long time, a professional symphonic orchestra was founded in Crimea and it performed classical, folkloric, modern and children music pieces. Today, there are many pieces in the repertoire belong to Crimean Tatars composers such as Y. Şerfedinova, İ. Bakşiş, E. Nalbanov, F. Aliyev. These compositors had also been working to collect yırs and published them. "Sabanın Saar Vaqtında", including 305 yırs, was published by İ. Bahşiş and E. Nalbandov in 1977. "Yanğıray Qaytarma" which includes more than 340 yırs, was published by Y. Şerfedinov in 1978. In recent years, F. Aliyev has been conducting such studies on yirs.

On the other hand, old migrates before the exile living in Romania and Turkiye, continued their activities. In Turkiye, Crimean Tatars has founded civil associations' in big cities and Tatar settlements such as İstanbul, Ankara, Eskişehir, Bursa, İzmit, Balıkesir, Çorum and ext. Thus, they lived their own culture, protected their folkloric structure and tried to not to forget their yırs, çıns as well as the other folk music and dance genres. Nowadays, there are very important musicians in Crimea such as, Server Kakura, Dilaver Osmanov, Cemil Karikov, Asiye Sale, Rüstem Memet, Seytabla Memetov. They've still been joining many cultural activities in Turkiye, Crimea, Romania, and Uzbekistan. Ensembles and the other musicians often visit these countries and perform Tatars folk music. In recent years, Crimean Tatars are frequently invited by each other and organize joint activities. Thus, ties from the past and the origin are strengthening and cultural relations are increasing gradually. On the other side, talented young musicians 
grow up. But, Crimean Tatars and their traditional music are negatively affected by the consumption of pop music that spreads among them.

As a result, the Crimean music has been living different interactions through the immigrations for almost 150 years and despite the stringent years, it could achieve to exist. But today, people, particularly living in Crimea, abandoned their traditional structures and genres gradually. Hence, Crimean Tatars, living in Turkiye and Romania, who are complaining about this situation, have started efforts to reduce these negative effects. Finally, change has always been and will. Each community, however, should determine its own change and identify the limits of this change by itself.

\section{References Cited}

Gaspirali, İ. 1911. Tercüman Newspaper. Bahçesaray.

Olesnitski, A.1910. Kırım Türkleri'nin Yırları. Simferopol.

Konçevskiy, A.; Filonenko, V.; Efetov,S. 1927. Pesni Krımskix Tatar. Simferopol.

Şerfedinov, Y. 1931. Kırım Tatar Yır ve Oyunları. Simferepol.

Feratov A. 1931. Kırım Yırları. Simferepol.

Bahşiş İ.; Nalbandov E. 1977. Sabanın Saar Vaqtında. Taşkent.

Şerfedinov Y. 1978. Yanğıray Qaytarma. Taşkent. 